\title{
The Boundaries Between Legend and Folktale: «The Devil as Bridge Builder» in the Catalan Tradition
}

\author{
Los límites entre la leyenda y el cuento popular: \\ «el diablo como constructor de un puente» en la tradición catalana
}

\author{
Carme ORIOL \\ (Universitat Rovira i Virgili) \\ carme.oriol@urv.cat \\ ORCID ID: 0000-0002-1785-3451
}

\begin{abstract}
The theme of the Devil offering to build a bridge in one night in exchange for the soul of the victim has a considerable presence in folk narrative and is internationally widespread. An analysis of the twenty seven Catalan versions featuring the devil as a bridge builder» as the main character shows that these stories vary in nature and can be ascribed to genres related to the legend and the folktale, such as the satanic legend, the explanatory tradition, the comic tale and the religious (pious) story.
\end{abstract}

KEYWORDS: The Devil's bridge, folk narrative, Catalan legends
RESUMEN: El tema del diablo que se ofrece para construir un puente en una noche a cambio del alma de la víctima tiene una notable presencia en la narrativa folclórica y cuenta con una amplia difusión internacional. El análisis de veintisiete versiones catalanas que tienen como protagonista el diablo como constructor de un puente muestra que estos relatos son de naturaleza diversa y que pueden adscribirse a géneros relacionados con la leyenda y el cuento popular, como son la leyenda satánica, la tradición explicativa, el cuento jocoso y el cuento religioso (piadoso).

PALABRAS-ClAVE: El puente del diablo, narrativa folclórica, leyendas catalanas

The theme of the Devil offering to build a bridge in one night in exchange for the soul of the victim has a considerable presence in folk narrative ${ }^{1}$ and is widespread internationally ${ }^{2}$. In the Catalan linguistic and cultural area the theme is present in at least twenty seven versions in the oral tradition.

In most of the versions, the story also serves to explain the origin of a bridge, a standing stone (the stone the Devil did not manage to put in place to finish the bridge), a spring, a water channel or similar.

\footnotetext{
${ }^{1}$ This article is part of the research by the Grup de Recerca Identitats en la Literatura Catalana (GRILC), established by the Catalan Government (2017 SGR 599) and is one of the results of a research project on Catalan folk literature, which has received funding from the Spanish Government's Ministry of Science, Innovation and Universities (PGC2018-093993-B-100 [MCIU/AEI/FEDER, UE]).

${ }^{2}$ This is, for example, the central theme of the types ATU 1191 and ATU 810A* and the international folktale catalogue (Uther, 2004) mention for these types versions from twenty two and twenty countries respectively.
} 
Taking into account the versions documented in the Catalan tradition, the theme of the Devil as a «builder» who requires the victim's soul in exchange appears in tales of different kinds ${ }^{3}$. This theme therefore makes it possible to reflect on the boundaries between genres, specifically between legend and folktale.

In analysing the versions, the most important difficulties which emerged in assigning the tales to genres were basically of two kinds. On the one hand, working from published versions highlighted how hard it is to know how far the author of the collection intervened in setting down the written version, as not all the versions used are transcriptions of audio recordings. On the other hand, contextual information is practically non-existent in the versions studied, which means that there is no way of knowing what function the stories had.

Despite these limitations, analysis of the versions allowed the stories to be placed in four groups: (1) satanic legend; (2) explanatory tradition; (3) swindler's novella; and (3) religious tale. To aid reflection on the topic, a representative version was chosen for each group and is written down in full or briefly summarised, then references are made to other versions which fall into the same group. Wherever possible, the versions used as a model are those with the highest probability of faithfulness to oral sources, being either transcriptions of audio recordings or the result of quality work to collect folk stories.

In two cases, the entire version is given; in the others, where the version is extended and complex (with forward and backward references, interruptions and repetition by the informant, etc.), a comprehensive summary of the version is given that does not affect the content of the narrative but which does make the text easier to understand. Nevertheless, where necessary, these summaries include exact phrases from the original, marked in italics to highlight important aspects in the analysis of the versions. For the summarized versions, this characteristic is indicated using square brackets at the end of the summary. In any case, the annex at the end of the article includes the complete original versions in Catalan.

The factors taken into account in the analysis concern the credibility, numinous nature and stylistic aspects of the stories, as can be seen in the commentaries on the versions.

\section{THE SATANIC LEGEND ${ }^{4}$}

1. «El pont major de Girona» (Rupit, Osona) (GRUP DE RECERCA FOLKLÒRICA D’Osona, El Folklore de Rupit i Pruit, 1984, pp. 175-176).

In Girona, a poor girl who worked as a house maid, tired of crossing the river Ter every day to take food to the workers, said that she would give herself to the Devil if he would build her a bridge. A gentleman appeared before her -it obviously had to happen, that punishment - and said, «On the stroke of midnight the bridge will be finished, but you will never be able to cross it». The poor girl was afraid [speaking quietly] and told her masters.

There were three cockerels in the house: the white one, the buff one and the black one. The black one was bad, on the dark side. The demons worked all night and built the main bridge in Girona, but before midnight the mistress of the house wet the cockerels with

\footnotetext{
${ }^{3}$ For the process when the tales transform from one genre to another and when the functions, goals or imaginations you find in the tale are changing, see the entry «Schwundstufe» in the Enzyklopädie des Märchens (Brednich, 2005). I am very grateful to Hans-Jörg Uther for his comments in relation to this term.

${ }^{4}$ This group is formed by only one version.
} 
lukewarm water and the black cockerel crowed. The demons lost and couldn't take the girl away, but she, poor thing, died of fright. [summarised].

This version was collected in 1981 in a rural area of Catalonia, in the village of Rupit, in the Osona area. The informant was Pere Font, who was seventy two years old at the time. The collectors, Jaume Aiats, Ignasi Roviró and Xavier Roviró (members of the Osona Folklore Research Group) explain in their book El Folklore de Rupit i Pruit (1984: 163) that the narrator of this tale «believes and relives what he has told as a true story». This is the only case in the whole corpus analysed where information was available about the «credibility» factor of the tale.

In this version, therefore, the credibility of the tale, which is considered to be a characteristic feature of legend as opposed to a folktale, would be a first objective indicator that the story should be placed in the category of legend.

A second factor to take into account is the numinous nature of the narrative. Satan and the devils personify the negative forces of numinous power and in this story they clearly exercise this power over humans. In the narrative, which would be in the satanic mode in the words of Heda Jason (1977: 21-22; 2000: 139), «satanic fear» ${ }^{5}$ (Pujol, 1994: 46) is made clear, i.e. the protagonist, who has had dealings with the Devil, realises the great danger she is in. The Devil says she will never be able to cross the bridge. The protagonist, who believes in the Devil's power, becomes frightened and this causes her to die. This belief in the malignant power of the Devil is shared by the narrator when he refers to the black cockerel as being «on the dark side».

The narrative has a tragic tone, as do many legends, and it is of an exemplary nature. The tale warns us about the danger involved in having dealings with the Devil.

The stylistic details also reinforce the story's character as a legend. The narrator is sorry for the girl and refers to her as «the poor girl»; he then jumps ahead of events and talks of her «punishment» as something inevitable which «had to happen». Later on he says that «the poor girl» was «frightened» and gives this information speaking quietly (as noted in the transcription), as if the matter really were a delicate one. Later on, he mentions that «the poor girl died of fright».

Even so, this story could also be considered a hybrid between the satanic legend (the dramatic part with the death of the protagonist) and the swindler's novella (the ingenious part), when it says «the mistress of the house wet the cockerels with lukewarm water and the black cockerel crowed; the demons lost and couldn't take the girl away».

\section{THE EXPLANATORY TRADITION ${ }^{6}$}

The stories in this group are distinguished by the fact that their main function is explanatory. They are intended to explain why a bridge has a stone missing or why a large stone near to the bridge is known as the Devil's Stone.

1. «El pont del Diable» (Batet, Garrotxa) (Romeu, Llegendes de la Garrotxa, 2004, (b) 46-47).

In Sallent, a village close to Santa Pau, in the middle of a plain there is a very tall stone. They say that the Devil wanted to build a bridge and that he wanted to complete it before midnight, before the cockerels crow, because that way he would obtain the soul of

\footnotetext{
${ }^{5}$ The notion is taken from the work of Pujol (1994), whose analysis was itself based on the classic book by Rudolf Otto on the psychology of religion, Das Heilige (1917). This notion is also related with the idea of «mysterium tremendum» expounded by Rudolf Otto in his essay.

${ }^{6}$ This group is formed by seven versions.
} 
a man who made a pact with him to make the bridge. But the cockerels crowed on the stroke of midnight, so that the Devil had to leave the last stone on the ground without finishing the bridge. Since then it has been called the Devil's Stone.

This story was told by Caterina Planella, resident of Batet, a little village in the interior of Catalonia, in the summer of $1951^{7}$. Apart from this information, the version contains no other contextual data that allows its meaning to be interpreted. Despite this, the text has some features that highlight its eminently explanatory character. These features are at the beginning and end of the story. Thus, the first sentence states where the story takes place and introduces the strange element that requires an explanation; that is, in the middle of a flat space there is a very tall stone. Next the story of the Devil as bridge builder is briefly developed, stating that the Devil leaves the work unfinished because he cannot complete it within the fixed period. However, this is narrated in a purely descriptive style, without the active intervention of the characters. Finally, the last sentence summarizes the story's intention, which is to explain why the stone is known as the Devil's Stone.

Other versions: 2. «La Cequia del Diable en Molvedre» (Massarrojos, València) (MARTÍNEZ, Llegendari valencià, 1995, pp. 180-181 [1st. ed. 1929]); 3. «El Pont d'Olvena» (Lasquarri, Baixa Ribagorça) (QUINTANA, Bllat Colrat! Literatura popular catalana del Baix Cinca, la Llitera i la Ribagorça. Vol. 1, 1997, p. 145); 4. «El pont de Diable» (La Seu d'Urgell, Alt Urgell) (ColL, Quan Judes era fadrí i sa mare festejava 1989, pp. 105-106; 5. «El pont del Diable» (Sant Privat d'en Bas, Garrotxa) (RoMEU, Llegendes de la Garrotxa, 2004, (a) 46-47); 6. «El pont del Diable» (Santa Pau, Garrotxa) (ROMEU, Llegendes de la Garrotxa, 2004, (c) 46-47); 7. «Un pont en una nit» (VERGÉS, Llegendes del Pla de l'Estany, 2008, p. 74).

\section{THE SWINDLER'S NOVELLA ${ }^{8}$}

The versions in this group have an entry in the international index, The Types of International Folktales (Uther, 2004), under number ATU 1191, in the section «Tales of the Stupid Ogre (giant, Devil)» and the part on «Souls Saved from the Devil». The plot in the most general terms, matching the description used in the Index of Catalan Folktales (Oriol/Pujol, 2008) for Catalan versions ${ }^{9}$, is as follows: the Devil undertakes to build a bridge in one night at the request of a mortal in exchange for the mortal's soul, but the mortal manages to avoid fulfilling his or her part of the bargain by means of a subterfuge.

However, many versions of this type display points of contact with ATU 810A*, specifically with the typical final motif of this type: the protagonist makes the cock crow early and the Devil disappears [G303.14, E452 ${ }^{10}$.

\subsection{ATU 1191}

\footnotetext{
${ }^{7}$ The municipality was joined with Olot (capital of the Garrotxa area) in 1971.

${ }^{8}$ In German: schwank; in French: facétie; in Spanish: cuento jocoso. This group is formed by fifteen versions.

${ }^{9}$ It was decided to put all the versions together as a single type of tale (ATU 1191) rather than separating them into two groups (ATU 1191 and ATU 810A*) as all of them share the mortal's pact with the Devil and subterfuge as the factor which thwarts the Devil's intentions. Moreover, the function of the tales is the same: they explain the existence of a large construction, generally a bridge.

${ }^{10}$ For the motifs G303.14 i E452, see Thompson (1955-1958).
} 
In these versions the pact is the following: the Devil offers to build a bridge in exchange for the soul of the first to cross it. The human sends an animal across (a donkey, a goat, etc. $)^{11}$.

1. «El pont del diable» (Abrera, Baix Llobregat) (BERTRAN, El rondallari català, 1989 , n. ${ }^{\circ} 60$, p. 154 [1st. ed. 1909 , p. 263]).

They say that the people of Martorell and those on the other side had been wanting to build a bridge over the river to get from one village to the other, but they never could; and one day the Devil appeared and said that he promised to do it if they would give him the soul of the first to cross it.

They said yes; and in one night the demons built the bridge, which is still there. The next morning they took along a cat, with some junk tied to its tail to frighten it, and the cat ran across it; and the Devil had to be content with that soul. As they hadn't said whether it had to be a beast's or a person's..!

The details of this version only show that it was collected at Abrera, a municipality near Martorell. In this version, no external information is available concerning the «credibility» factor; therefore, it is necessary to see what other factors the text itself can offer.

First of all, it is clear that the narrative is humorous in tone and has an ending which is positive for the human; the Devil, on the other hand, is the one who is tricked. In fact, the story is told as a swindler's novella, i.e. a contest of ingenuity between a human (intelligent) and the Devil (stupid), and therefore fits perfectly into the group of «Tales of the Stupid Ogre (giant, Devil)».

Secondly, there are details which reinforce the humoristic nature of the version, such as when the narrator says a cat was made to cross the bridge «with some junk tied to its tail» and especially in the last phrase, «As they hadn't said whether it had to be a beast's or a person's!».

Other versions: 2. «El pont del diable» (MeSTRES, Tradicions, 2009, n. ${ }^{\circ}$ 70, pp. 71-72 [1st. ed. 1895]); 3. «El pont del diable» (Tarragona, Tarragonès) (ORIOL, El patrimoni oral a les comarques de Tarragona. Relats tradicionals, 2005, pp. 15-16); 4. [«El pont del diable»] (SALVAT, La Ciutat i el Camp de Tarragona, 1969, pp. 10-11).

In the versions with the characteristic motif of ATU $810 A^{*}$ the pact is the following: the Devil offers to build a bridge in one night. The human makes the cock crow early, the Devil takes this to mean it is daybreak and, as he has been unable to complete the bridge, goes away without the mortal's soul. In some of these versions, the Devil is referred to as «en Banyeta» (approximately equivalent to «Old Nick»). This is a form used by adults to treat the Devil as a character in tales, with the clear intention of playing him down as a figure and making him into an accessible rather than a feared character.

Other versions: 5. «El Pont del Diable» (AMADES, Les millors llegendes populars, 1979, pp. 281-282 [1st. ed. 1950, n. ${ }^{\circ} 1528$ (a), pp. 1114-1115 titled «La pedra del diable»]); 6.

\footnotetext{
${ }^{11}$ For the study of this type at a international level, see the entry «Brückenopfer» in the Enzyklopädie des Märchens (Moser-Rath, 1977).
} 
«El Pont del Diable» (AMADES, Les millors llegendes populars, 1979, pp. 281-282 [1st. ed. 1950, n. ${ }^{\circ} 1528$ (b), pp. 1114-1115 titled «La pedra del diable»]); 7. «La nena, el gall i el dimoni» (Puigcerdà, Cerdanya) (CERDÀ, Contalles de Cerdanya, 1961, pp. 31-36; 8. «La font del Dimoni» (La Seu d'Urgell, Alt Urgell) (Coll, Quan Judes era fadrí i sa mare festejava, 1989, pp. 99-100; 9. «El pont del Diable (una altra versió)» (Cardona, Bages) (MARTín, Carme (ed.), Llegendes i contalles del Bages, 1996, p. 85; 10. «Pactes» (ROMEU, Materials $i$ estudis de folklore, 1993, n. ${ }^{\circ}$ 54a, p. 123 [1st. ed. 1950]); 11. «Pactes» (RoMEU, Materials i estudis de folklore, 1993, n. ${ }^{\circ}$ 54b, p. 123 [1st. ed. 1950]; 12. «El diable i la donzella» (SOBERANAS, Llegendes històriques de Tarragona, 2002, p. 43 [1st. ed. 1965]); 13. «El jugador empedreït» (SOBERANAS, Llegendes històriques de Tarragona, 2002, p. 45 [1st. ed. 1965]); 14. [sense títol] (VERDAGUER, Rondalles, 1992, [f. 18r], pp. 382-283); 15. «Un pacte amb el dimoni» (VILARMAU, Folklore del Lluçanès, 1997, pp. 262-263 [edition made from unpublished materials from 1947] ${ }^{12}$.

\section{THE RELIGIOUS (PIOUS) TALE ${ }^{13}$}

1. «El de la mà peluda» (Barcelona, Barcelonès) (BERTRAN, El rondallari català, 1909, p. 263. [2a. ed. 1989, n. ${ }^{\circ}$ 61, pp. 155-156]).

Once upon a time there was a girl deeply devoted to the Virgin Mary who was taking great care of some lilies she had at her window because she wanted to take them to a figure of Our Lady nearby. So you see, one evening there was a knock at the door, and there was a gentleman asking to be let in. They have supper, and afterwards the girl's father starts with the rosary; just then the gentleman gets up, says good night and goes off to bed.

At the stroke of midnight the girl, who had still not gone to sleep, went out to the window to bring in the lilies, because it was raining and she was afraid they might be ruined. Just then she saw a hairy black hand coming down from the window of the upstairs room; she screamed, took in the lilies and locked the window; she was unable to sleep all night, thinking about that horrible hand.

This girl had a fiancé who lived on the other side of the village and she had to cross a river to get there. As it had rained all the night long it was impossible to cross it. Her fiancé had to go off to the war the next day and both of them were waiting for daybreak so that they could say goodbye to each other.

When she got up in the morning and saw how high the river was, she became very sad. She picked the lilies and took them to the Mother of God. The gentleman she saw the night before appeared on the road and asked her why she was crying. She told him, and the man said that if she gave him her soul he would build her a bridge over the river before twelve so that she could say goodbye to her fiancé. The poor girl, not realising what she was doing, she agreed, and the gentleman disappeared. But then she thought about it and regretted her decision. Crying, she fell at the feet of the statue of the Virgin, begging forgiveness for having given away her soul and begging that the bridge not be finished by twelve.

Meanwhile, by the river, a whole battalion of demons of all sizes appeared and started building the bridge: and, work, work, work away, it was nearly twelve and the bridge was almost finished; but in the end it struck twelve and there was still one stone left to lay. As

12 These versions present great similarities with others from Portugal (Cardigos, 2006) and Spain (Camarena, 2003) in some motifs as: the girl has to do a hard work every day for get water; there are three cockerels in the house; the black cockerel sings before the bridge is finished, etc. I would like thank Isabel Cardigos, Paulo Correia and José Manuel Pedrosa very much for kindly providing me with some Portuguese and Spanish versions of ATU 810A*.

${ }^{13}$ This group is formed by four versions. 
the Devil had not met his side of the bargain, the bridge fell down and the Virgin Mary appeared right there, took the girl and carried her to the other side of the river so that she could see her fiancé. And Our Lady also stopped the fiancé from having to go away to war; and they got married and lived happily ever after. [summarised].

In the book El rondallari català (Bertran, 1909), this version falls into the group of «legends, moral examples and cases». This is a version which combines features of legends and folktales.

The legendary aspect comes from, firstly, the numinous nature of some of the characters: the Devil and the Virgin Mary and the power they display. The behaviour of the protagonist combines features related to «satanic fear» (the narrator comes close to this emotionally by saying «poor girl») and «holy devotion». In this duality of powers, holy power wins. Secondly, the protagonist shows herself to be very devout, repents of her behaviour and asks the Virgin Mary for help. Her good behaviour from a religious point of view is what saves her. The narrative is therefore of an exemplary nature. Given these features, at the outset this should be considered as a holy legend.

However, its folktale-like aspect comes from the presence of stylistic markers characteristic of this genre. The action in the story is set in an indeterminate time and place. Moreover, the story contains other features characteristic of folk tales such as the formula at the beginning («Once upon a time there was...») and that at the end («They got married and lived happily ever after») and the use of specific connectors like «vet aquí» and «treballa que treballaràs» (translated above as «so you see» and «work, work, work away»). Finally, it is worth pointing out that the bridge is destroyed, therefore leaving no physical trace, so that there is no link to a specific location as there would be in a legend.

The folk tale style, which links the story to a communicative situation in which the most important thing is its educational function, is what makes it possible to consider this story as a religious folk tale.

Other versions: 2. «La pedra del diable» (CONSTANS, Rondalles, 2005, pp. 107-110 [1st. ed. 1952]); 3. «La font del miracle» (MESTRES, Tradicions, 2009, n. . 46, pp. 53-54 [1st. ed. 1895]); 4. «Pont del diable de Castellfollit de la Roca»(Orís, Osona) (RomeU, Llegendes de la Garrotxa, 2004, p. 109).

In these versions the pious element is less pronounced. The protagonist simply shows signs of repentance and asks God or the Virgin Mary for help. Finally, divine assistance saves the protagonist.

\section{CONCLUSIONS}

An analysis of the twenty seven Catalan versions featuring «the Devil as bridge builder» as their protagonist shows that these stories vary in nature and can be presented in the form of satanic legend, explanatory tradition, swindler's novella or religious (pious) tale.

The most numerous stories are those in the form of folktales (swindler's novella -ATU 1191 and ATU 810A*_ or religious tale), with nineteen versions. Next are the explanatory traditions, with seven versions, which also make up a quantitatively important group. Finally, the group of satanic legends is made up of just one version. These results show that, in the versions considered, the figure of the Devil is seen more as a character of folk tales who can be beaten by humans than as an evil character to be feared. 


\section{BIBLIOGRAPHY}

AMADES, Joan (1979): Les millors llegendes populars, Barcelona, Selecta [1st. ed. 1950]).

[ATU] UTHER, Hans-Jörg (2004): The Types of International Folktales. A Classification and Bibliography, FFC, 284-286, Helsinki, Suomalainen Tiedeakatemia.

BERTRAN, Pau (1989): El rondallari català, Barcelona, Alta Fulla [1st. ed. 1909].

BREDNICH, Rolf Wilhem (2005): «Schwundstufe». Enzyklopädie des Märchens, 12, 1, pp. 497-596.

Camarena, Julio and Chevalier, Maxime (2003): Catálogo tipológico del cuento folklórico español. Cuentos religiosos, Madrid, Centro de Estudios Cervantinos.

CARDigos, Isabel (2006): Catalogue of Portuguese Folktales, FFC, 291, Helsinki, Suomalainen Tiedeakatemia.

CERDÀ, Jordi Pere (1961): Contalles de Cerdanya, Barcelona, Barcino.

Coll, Josep (1989): Quan Judes era fadrí i sa mare festejava, Barcelona, la Magrana.

Constans, Lluís G. (2005): Rondalles, Banyoles, Centre d'Estudis Comarcals [1st. ed. 1952]).

GRUP DE RECERCA FOLKLÒRICA D'OsONA (1984): El Folklore de Rupit i Pruit, Vic, Eumo.

JASON, Heda (1977): Ethnopoetry: Form, Content, Function, Forum Theologiae Linguisticae, 11, Bonn, Linguistica Biblica.

JASON, Heda (2000): Motif, Type and Genre. FFC, 273, Helsinki, Suomalainen Tiedeakatemia.

MARTín, Carme (ed.) (1996): Llegendes i contalles del Bages, Manresa, Angle editorial.

MARTÍNEZ, Francesc (1995): Llegendari valencià, Alacant, Generalitat Valenciana / Institut de Cultura Juan Gil-Albert / Diputació Provincial d'Alacant [1st. ed. 1929]).

Mestres, Apel·les (2009): Tradicions, Valls, Cossetània [1st. ed. 1895]).

MOSER-RATH, Elfriede (1977): «Brückenopfer», Enzyklopädie des Märchens, 2, pp. 838842.

ORIOL, Carme (2005): El patrimoni oral a les comarques de Tarragona. Relats tradicionals, Tarragona, Diputació de Tarragona.

OrIol, Carme and Pujol, Josep M. (2008): Index of Catalan Folktales, FFC, 294, Helsinki, Suomalainen Tiedeakatemia.

Pujol, Josep M. (1994): «Variacions sobre el Diable». Revista d'Etnologia de Catalunya, 4, pp. 44-57.

QUINTANA, Artur (1997): Bllat Colrat! Literatura popular catalana del Baix Cinca, la Llitera i la Ribagorça, I, Calaceit, Instituto de Estudios Turolenses / Associació Cultural del Matarranya / Carrutxa. 
ROMEU I FIGUERAS, Josep (1950): «Mites populars pirinencs (Alt Ripollès i Vall de Ribes de Freser)», Pirineos, 6, 15-16, pp. 137-183. Reproduced in ROMEU I FIGUERAS, Josep (1993): Materials i estudis de folklore, Barcelona, Alta Fulla, pp. 93-125.

ROMEU I FIGUERAS, Josep (1993): Materials i estudis de folklore, Barcelona, Alta Fulla.

RoMeU i Figueras, Josep (2004): Llegendes de la Garrotxa, Sant Vicenç de Castellet, Farell.

Salvat, Joan (1969): La Ciutat i el Camp de Tarragona, Tarragona, Diputació.

SoBERANAS, Amadeu-J (2002): Llegendes històriques de Tarragona, Tarragona, El Mèdol [1st. ed. 1965].

ThOMPSON, Stith (1955-1958): Motif-index of Folk Literature, 6 vols, Bloomington, Indiana University Press.

UTHER, Hans-Jörg (2004): The Types of International Folktales. A Classification and Bibliography, FFC, 284-286, Helsinki, Suomalainen Tiedeakatemia.

VERDAGUER, Jacint (1992): Rondalles, Barcelona, Barcino.

Verges, Àngel (2008): Llegendes del Pla de l'Estany, Sant Vicenç de Castellet, Farell.

VILARMau, Josep M. (1997): Folklore del Lluçanès, Prats de Lluçanès, Ajuntament / Barcelona, DINSIC Publicacions Musicals. [edition made from unpublished materials from 1947]. 


\section{ANNEX}

\section{TEXT 1}

«El pont major de Girona» (Rupit, Osona) (GRUP DE RECERCA FOLKLÒRICA D’OSONA, El Folklore de Rupit i Pruit, 1984, pp. 175-176).

Pere Font. Rupit. 13-VII-81.

Una criada, tipa de passar el Ter, diu que es daria al dimoni si li feia un pont. El dimoni se li presenta i li diu que a les dotze serà fet el pont, però que ella mai no hi passarà.

Abans de les dotze la mestressa va ruixar els galls amb aigua tèbia i va cantar el gall negre. Els dimonis van perdre, però la criada es va morir de l'espant. Va quedar una pedra per posar, que la van trobar al Camp de Santa Pau.

A Girona, en el pont major de Girona, hi havia una pobra noia que d'abantes, abans de fer el pont aquell, estava per criada — aquesta senyora - amb una casa més cap al poble, a l'altre costat del Ter. I cada dia menava terra a l'altre costat del Ter, que baixava. Beno, està bé. I la pobra senyora, me cago amb Déu, cada dia es 'via de descalçar per portar els àpats als trebaiadors. I un dia enrabiada, diu: peu eixut!

- Me cago amb Déu, jo em daria amb el dimoni si demà pogués passar amb el

I se li presenta un senyor - aquella cosa es veu que ja havia haver de passar, el càstig aquet-, se li presenta un senyor i diu:

—Al punt de les dotze de la nit el pont serà fet, però mai poràs passar amb el peu eixut.

Cago amb Déu, [parla baix] la pobra es va quedar assustada. Va arribar a casa seu —allà on.t estava — i ho va explicar, la pobra. Diu:

-Beno. Aqueixa nit ja cal que vetllem!

I a aquella casa hi 'via tres galls: hi 'via el blanc, i el ros i el negre. I la cançó cantava: «Canti el blanc, canti el ros mentre el negre no ès fos» ${ }^{1}$. El negre era el negre dolent, de la part dolenta. I amb una nit, ja veis si eren colla aquet collons de 'mundícia, a fer el pont major de Girona. I la pedra que va fallar, que el gall va cantar... La senyora de la casa anà'ls-hi tirant aiga tèbia a.n aquell tres pollastres. I abans de passar el punt de les dotze de la nit:

Quicaraquic!

Ja va haver gonyat, però ella, la pobra, d'espant ella va morir; però no se'n varen poguè'-se-la emportar. Perquè llur gust era, havent fet el pont, per emportar-se la xicota.

I a la radera pedra de la brana, que de què se sap, la trencaven a Pedraforca. Acabaven de petar el punt de les dotze: «-Quicaraquic.» La radera pedra de la brana la van deixà'-la anar al camp de Santa Pau — això ès aquí a la frontera-. I van agafar les mides, ${ }^{2}$ la van anar a amidar, i s'avenia exacta. Exacta s'avenia amb la pedra de la brana. I aquella pedra de la brana, collons, 'nar-hi tot sovint, posar-hi una atra pedra: però tot sovint aquella pedra tornava a quedar desfeta, eh!, la brana. $\mathrm{I}^{1} \mathrm{l}^{3}$ atre tot ferm com una mala cosa. 
Va passar, això, a Girona. I es veu que aquet càstig ja hi havia haver de ser perquè hi havia aquet tres pollastres: i el blanc, i el ros i el negre. I la cançó cantava: «Canti el blanc, canti el ros, mentre el negre no ès fos.»

Ho cantaven, això?

Ells [els dimonis] ho cantaven. Ells [els de la casa] sentien la veu aquesta tota la nit. Sentien aquesta veu però no veien a ningú.

Aquesta narració també ens la va explicar en Francesc Rovira.

1. En Pere Font anomena cançó les dites i frases fetes.

2. La gent del poble.

3. $/ \operatorname{lọ}^{\prime} \%$

\section{TEXT 2}

«El pont del Diable» (Batet, Garrotxa) (RoMEU, Llegendes de la Garrotxa, 2004, (b) 4647).

Al Sallent - poblat proper a Santa Pau-, al mig d'un pla hi ha una pedra molt alta. Diuen que el diable volia fer un pont abans de les dotze de la nit, abans que els galls no cantessin, perquè així tindria l'ànima d'un home que va pactar amb ell perquè fes aquella construcció. Però els galls van cantar al punt de la mitjanit, de manera que el diable va haver de deixar a terra l'última pedra que li quedava per acabar l'obra. Des d'aleshores en diuen la Pedra del Diable.

\section{TEXT 3}

«El pont del diable» (Abrera, Baix Llobregat) (BERTRAN, El rondallari català, 1989, n. ${ }^{\circ}$ 60, p. 154 [1st. ed. 1909, p. 263]).

Diu que ja feia temps que els de Martorell i els de l'altra banda volien fer un pont al riu per poder passar de l'un poble a l'altre, però mai podien; i un dia es va presentar el dimoni i va dir que ell es comprometia a fer-lo si li donaven l'ànima del primer que hi passés.

Van dir que sí; i els dimonis en una nit van fer el pont, que encara és existent. A l'endemà de matí hi van portar un gat, amb un trasto lligat a la cua perquè s'esporuguís més, i el gat corrents hi va passar; i el dimoni es va haver d'acontentar amb aquella ànima. ¡Com que no havien dit si fóra de bèstia o de persona...!

\section{TEXT 4}

«El de la mà peluda» (Barcelona, Barcelonès) (BERTRAN, El rondallari català, 1909, p. 263. [2a. ed. 1989, n. $^{\circ} 61$, pp. 155-156])

Una vegada hi havia en una casa una noia molt devota de la Mare de Déu, i cuidava molt una mota de lliris que tenia a la finestra en una torreta, perquè els volia portar a una marededeu que hi havia allí prop.

Vet aquí que un vespre truquen a la porta, i es presenta un senyor que demanava acolliment. Van sopar, i acabat de sopar el pare de la noia comença el rosari; aixís que ho sent aquell senyor, s'alça, demana que li ensenyin el seu quarto, dóna el bona-nit i se'n va a dormir. 
Quan va tocar les dotze de la nit, la noia, que encara no havia pogut aclucar l'ull, va sortir a la finestra a endreçar els lliris, perquè plovia i tenia por que no es fessin malbé. Ella que s'adona d'una mà tota peluda i negra que baixava de la finestra del quarto de dalt: pega un xiscle, entra els lliris i tanca; i en tota la nit no va poder dormir, pensant en aquella mà tan lletja.

Aquesta noia tenia un promès que vivia a l'altra part del poble i s'havia de passar un riu per anar-hi, i com que tota la nit havia plogut, el riu venia molt gros, que era impossible traspassar-lo. El promès havia de marxar a la guerra l'endemà, i tots dos esperaven que fos de dia per poder-se despedir.

Quan ella es va llevar i va veure que el riu venia tan gros, es va entristir molt. Cull els lliris i, reclamant-se a la Mare de Déu, se'n va a portar-los-hi.

Pel camí que va ser, se li va aparèixer aquell senyor i li va preguntar per què plorava; ella l'hi va explicar, i el senyor li va dir que, si li dava la seva ànima, li faria un pont abans de les dotze sobre el riu, per poder-se despedir del seu promès; i la pobra noia, sense saber lo que es feia, li va respondre que sí, i el senyor va desaparèixer. Però, encara aquest senyor no va ser fora, ella es va repensar i se'n va penedir; i tota plorosa se'n va anar als peus de la Mare de Déu, demanant-li perdó d'haver dat la seva ànima i suplicantli en gran manera que no estés el pont acabat a les dotze.

Mentrestant allí en el riu van sortir tot un batalló de dimonis de totes mides i es van posar a fer el pont; i, treballa que treballaràs, ja eren vora les dotze i el pont ja s'acabava; però a l'últim toquen les dotze i encara hi faltava una pedra. Com que el dimoni va faltar al tracte, el pont se'n va anar a terra i allí mateix es va aparèixer la Mare de Déu, va agafar la noia i la va passar a l'altra banda del riu perquè pogués veure el seu promès. I diu que la Mare de Déu també va fer que el promès no hagués de marxar a la guerra; i es van casar i van viure feliços per sempre.

Fecha de recepción: 3 de agosto de 2018 Fecha de aceptación: 29 de mayo de 2019

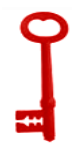

